\title{
THE FUTURE OF TRANSPORT AND COMMUNICATIONS IN EUROPE
}

\author{
Michael Wegener*
}

\begin{abstract}
The completion of the Single European Market and the opening of eastern Europe present new possibilities for the countries of the European Community. At the same time these countries are facing the same socioeconomic developments as other countries in the world such as the globalisation of the economy, the emerging information society, the deepening gap between North and South and the growing risks for the global climate. Before this background, transport and communications play an important role in shaping the future of Europe.

The paper reports on three scenario writing projects conducted under the auspices of the European Science Foundation and for the Commission of the European Communities. In the three projects, scenarios were developed for transport and communications in general, for the future of cities, and for the regional impacts of the Channel Tunnel and its related infrastructure.
\end{abstract}

\section{Introduction}

The 1990s will be a decade of fundamental change for Europe. No other continent of the world is so deeply affected by the collapse of the socialist systems in the Soviet Union and the east European countries. In the light of this collapse, the west European model of a federation of democratic countries with market economies becomes more and more attractive. It may well be that the European Community will grow during this decade from its present 340 million people to become the world's most powerful economic region with more than 500 million consumers.

At the same time the countries of the Community are facing the same long-term socioeconomic developments as other countries of the world such as the globalisation of the economy, the emerging information society, the deepening gap between North and South and the aggravating risks for the global climate.

* Dr.-Ing., Institute of Spatial Planning, University of Dortmund, Germany
These changes will put great pressure on the process of political and economic integration in the Community. The completion of the Single European Market in 1993 and further steps towards a monetary and political union critically depend on the harmonisation and equalisation of living conditions and economic opportunities in all parts of the Community. The unification of Germany has already demonstrated the enormous adjustment problems associated with the transformation of a planned economy into a market system.

Before this background, transport and communications play an important role in shaping the future of Europe. Efficient transport and communication links between suppliers, producers and consumers within regions as well as between regions and across national boundaries are vital for the growth and global competitiveness of the European economy. Transport and communications are indispensable for modern lifestyles based on high levels of mobility and personal interaction. Transport and communications are essential for binding the regions and countries together and for reducing the disadvantage of the peripheral regions against the core. 
The close association of transport and communications with economic development is witnessed by their stupendous growth in the past. In line with the growth in gross national product, in the last two decades passenger transport in Europe has almost doubled, while goods transport increased by two thirds and telecommunications by a factor of five, and there are no signs of slowing down of this growth.

The unconstrained growth in transport, however, has created severe technical, social and environmental problems, especially in the most industrialised regions in north-west Europe. As most of this growth has occurred in road and air traffic, already today urban trunk roads, motorways, air corridors and airports are notoriously congested. Transport-induced energy consumption, air pollution, noise intrusion and accidents continue to grow despite all efforts to reduce them. In the face of unlimited further growth, there is a widespread feeling of crisis (see for instance Nijkamp et al., 1990; Group Transport 2000 Plus, 1990; European Round Table of Industrialists, 1991; and Commission of the European Communities, 1991).

At the same time, there is a serious lack of transport and communications infrastructure in the less developed regions of the Mediterranean and eastern Europe. If the large economic disparities between these regions and the more affluent core regions of Europe are to be reduced, massive transport investments are necessary. Even greater sums are required to bring the transport and communications infrastructure of east European countries up to west European standards. It has been estimated that the restoration of the East German transport system alone will cost 277 billion marks (¥19 trillion), even larger sums will undoubtedly be required for other east European countries.

The gap between the core and peripheral regions will be further deepened by the advent of new levels of transport and communications infrastructure. The emerging European high-speed rail network in combination with new transnational links such as the Channel Tunnel, the new transalpine rail links and the Öresund and Belt crossings as well as new telecommunication networks such as ISDN will first connect the large agglomerations and further increase the peripherality of regions which are not connected.
In the face of these conflicting tendencies, the future of transport and communications in Europe is extremely uncertain. Will the forces dominate which promote further expansion of transport infrastructure for the sake of continued economic growth, or will the opposition based on environmental concerns win public support, or will policies to reduce interregional disparities be pursued?

These are the issues discussed in this paper. It reports on three scenario writing projects conducted under the auspices of the European Science Foundation and for the Commission of the European Communities. In the three projects, scenarios were developed for transport and communications in general, for the future of cities, and for the regional impacts of the Channel Tunnel and its related infrastructure (see Masser, Svidén and Wegener, 1992; Kunzmann and Wegener, 1991; and ACT, IRPUD and ME\&P, 1991).

\section{Socioeconomic Trends}

Transport and communications are secondary or derived human activities that cannot be seen in isolation from the social, economic and political development of a society. Therefore, at first major social and economic change processes currently taking place in Europe are briefly described. Table 1 summarises these changes and their consequences for transport and communications.

\section{Population}

The most important demographic trend in most European countries is the decline in fertility. If only natural change is considered, most European countries are likely to experience a fall in population in the next decades. However, this decline is likely to be more than offset by a new wave of international migration from east Europe and the Mediterranean. One impact of declining birth rates is the progressive ageing of the population. Sweden and Germany are likely to be the leaders, in the world only surpassed by Japan.

The growth in population will have obvious impacts on the demand for transport and communications. The ageing of the population will bring an increase in demand for public transport and a relative decline in private car usage. 
Table 1. Socioeconomic trends and their impact on transport and communications.

\begin{tabular}{|c|c|c|}
\hline Field & Socioeconomic trends & $\begin{array}{l}\text { Implications for transport } \\
\text { and communications }\end{array}$ \\
\hline Population & $\begin{array}{l}\text { Decline of birth rates; new } \\
\text { international migration from } \\
\text { eastern and southern Europe; } \\
\text { ageing of the population. }\end{array}$ & $\begin{array}{l}\text { Growing demand for transport and } \\
\text { communications; increased demand } \\
\text { for public transport; relative } \\
\text { decline in private car usage. }\end{array}$ \\
\hline Lifestyles & $\begin{array}{l}\text { Decreasing household size; } \\
\text { higher labour force partici- } \\
\text { pation of women; new life- } \\
\text { styles; shorter work hours. }\end{array}$ & $\begin{array}{l}\text { Higher car ownership, increasing } \\
\text { mobility; increasing use of per- } \\
\text { sonal telecommunications; more } \\
\text { leisure and tourist trips; }\end{array}$ \\
\hline Economy & $\begin{array}{l}\text { Decline in manufacturing and } \\
\text { agriculture, growth of ser- } \\
\text { vice activities; reorganisa- } \\
\text { tion of production and dis- } \\
\text { tribution; liberalisation, } \\
\text { internationalisation. }\end{array}$ & $\begin{array}{l}\text { Growth of goods transport, mostly } \\
\text { by road; integrated logistic sys- } \\
\text { tems; increased use of business } \\
\text { telecommunications; increased in- } \\
\text { ternational passenger and goods } \\
\text { transport; deregulation. }\end{array}$ \\
\hline Environment & $\begin{array}{l}\text { Energy use and emissions of } \\
\text { transport increase; growing } \\
\text { land demand for transport; } \\
\text { traffic noise and traffic } \\
\text { safety unsolved problems. }\end{array}$ & $\begin{array}{l}\text { Speed limits, stricter emission } \\
\text { standards, car restraint, pedes- } \\
\text { trianisation, improved public } \\
\text { transport; more rigorous traffic } \\
\text { restraint policies likely. }\end{array}$ \\
\hline $\begin{array}{l}\text { Regional } \\
\text { Development }\end{array}$ & $\begin{array}{l}\text { Increasing interregional dis- } \\
\text { parities in Europe; fastest } \\
\text { growth in core regions; rela- } \\
\text { tive decline in old industri- } \\
\text { al and peripheral regions. }\end{array}$ & $\begin{array}{l}\text { Further concentration of trans- } \\
\text { port and communication flows in } \\
\text { core regions; decentralisation } \\
\text { policies? }\end{array}$ \\
\hline $\begin{array}{l}\text { Urban and } \\
\text { Rural Form }\end{array}$ & $\begin{array}{l}\text { Counterurbanisation in north- } \\
\text { west Europe, continued urban } \\
\text { growth in the South; new city } \\
\text { hierarchy; intraregional dis- } \\
\text { persal; reurbanisation? }\end{array}$ & $\begin{array}{l}\text { Increasing congestion in largest } \\
\text { cities; rigorous traffic control; } \\
\text { coexistence with car in smaller } \\
\text { cities; public transport poli- } \\
\text { cies; suburbia car-dependent; }\end{array}$ \\
\hline
\end{tabular}

\section{Lifestyles}

In all European countries the size of the average household has fallen substantially. With households becoming smaller, more women tend to work. Up to eighty percent of all households in inner cities are one-or-two person households: young workers, students, pensioners, yuppies ('young urban professionals') or dinks ('double income no kids') or affluent 'senior citizens' of the 'silver' generation. A consequence of new technologies in manufactur- ing and services is a marked reduction of work hours and concomitantly an enormous increase in the amount of time devoted to leisure activities and a massive expansion of the leisure and tourist industries.

All the above factors tend to result in higher car ownership and increased demand for personal mobility and communication. By the year 2020, leisure and tourist activities may account for forty percent of all land transport and sixty percent of all air transport. 


\section{Economy}

Throughout Europe the decline in traditional manufacturing industries has been compensated for by the expansion in service activities, while agricultural employment declined. However, behind the shift in employment are more fundamental changes in the total organisation of production and distribution. The introduction of computerisation in manufacturing has brought a new flexibility of the production process: economies of scale are replaced by economies of scope. This has become possible by an increasing vertical integration of the production process from supply to delivery by computer control and telecommunications. Earlier steps in the assembly chain are contracted out to outside suppliers who have to synchronise their operations and delivery with the main production schedule ('just-in-time') increasingly over long distances.

These changes of the economy have significant implications for spatial structure and goods transport: Industrial locations more than ever depend on good transport access to suppliers and markets. Information-intensive industries, in particular of the highest level, tend to concentrate in the agglomerations and so contribute to their congestion. The logistics revolution results in substantial further growth in road goods transport. The completion of the Single European Market in 1993 leads to a dramatic expansion in international exchange and so growth in both passenger and goods transport.

\section{Environment}

Environmental problems are becoming the most important issue in transport. Despite more energy-efficient and cleaner cars, in absolute terms transport-generated energy use and emissions have increased due to increasing numbers of cars and trucks and the trend to longer trips, higher speeds and larger vehicles. In densely populated Europe, land consumption for transport infrastructure has become a serious problem. The most obnoxious environmental impact of transport is traffic noise. Despite great advances in automobile safety, transport continues to demand its death toll.

The European countries have reacted to the growing negative impacts of transport by various measures such as speed limits, stricter emission standards, car restraint measures, pedestrianisation and improved or new public transport systems. In spite of this, the opposition to new large-scale infrastructure projects is mounting. It is likely that in the future even more rigorous policies to constrain traffic will be implemented.

\section{Regional Development}

The differences in income, employment, infrastructure and provision of services between the regions of Europe are still enormous, and they are likely to become more pronounced: The regions in the core of Europe will continue to benefit from economic structural change and the integration of Europe, except the old industrial regions, which will continue to decline. The peripheral regions will grow, but less than the core regions. The most likely scenario of regional development in Europe looks like Figure 1:

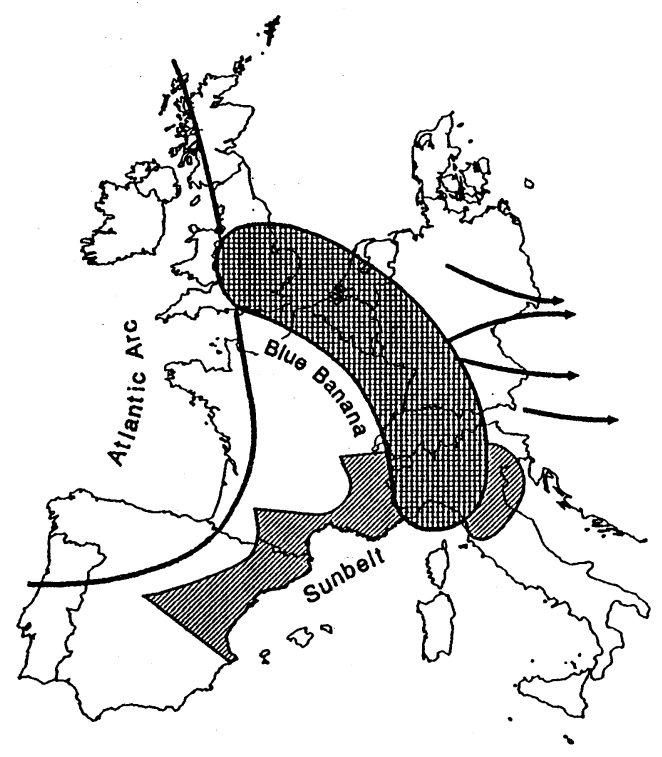

Figure 1. The most likely growth regions of Europe: the 'Blue Banana' and the 'Sun Belt' (RECLUS, 1989).

There will be a curved zone of intensive development stretching from south-east England across the Channel through Benelux, south-west Germany and Switzerland to Lombardy (the 'Blue Banana'), where it meets with another growth zone developing along the Mediterranean (the 'Sun Belt'). With the exception of: the Ile de France, centres outside these zones will be at a relative disadvantage. 
Current transport and communications policies are likely to reinforce these tendencies. The planned high-speed rail links and new motorways will largely follow present transport corridors and so further improve the accessibility between the core regions at the expense of the periphery. Deregulation of air transport will enhance the position of the present major airports serving as hubs routing flights to secondary airports and concentrating traffic in the core regions. Advanced telecommunication services will be available first where high-volume demand will make them profitable, and this will be in the existing centres. The overall impact will a further concentration of transport and communication flows in the core regions.

\section{Urban and Rural Form}

The 1950s and 1960s were a period of rapid urban growth all over Europe. In the 1970 s the urbanisation rate started to decline. At the same time smaller cities at the urban fringe started to grow. Counterurbanisation tendencies are found primarily in the most industrialised countries in north-western Europe, whereas in the Mediterranean and east Europe the urbanisation process prevails. However, not all cities in a country follow a common pattern. The new urban hierarchy divides cities across national boundaries into 'successful' and 'unsuccessful' cities (see Figure 2).

Successful cities are the two 'global' metropoles London and Paris and the small number of 'Euro-Metropoles', which flourish with the intensification of international trade and information flows, and some regional centres with a favourable combination of locational factors and the large number of small towns at the fringe of large agglomerations. All other cities are the losers, with old industrial cities and remote rural towns suffering most from urban decline.

The common experience for both winner and loser cities has been spatial deconcentration. The results are generally considered to be negative: longer trips, more energy consumption, pollution, accidents, excessive land consumption and problems of public transport provision in low-density areas. All over Europe cities have undertaken efforts to revitalise their inner cities, in some cases with remarkable success.

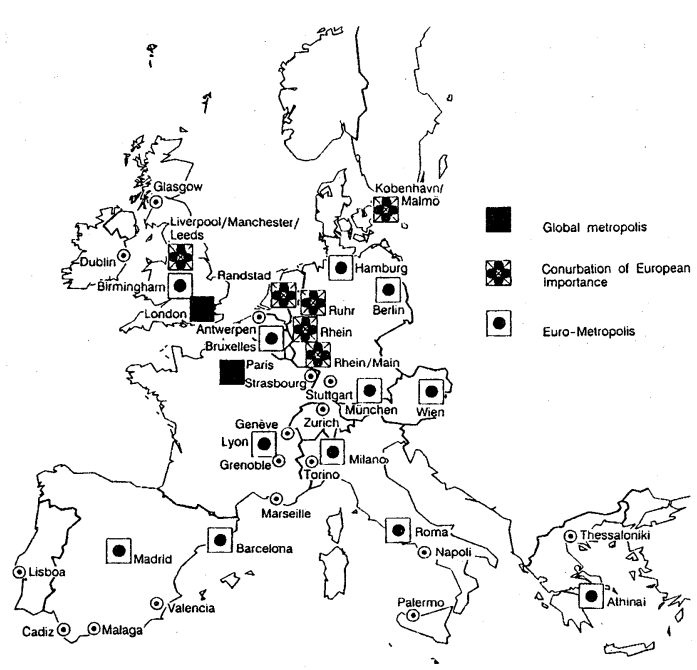

Figure 2. The urban system in western Europe: Global and Euro-Metropoles and conurbations (Kunzmann and Wegener, 1991).

The impacts of these trends in urban development on transport and communications are: The largest cities will suffer under increasing congestion and will have to resort to rigorous measures of traffic control. Smaller cities are likely to be more successful in peaceful coexistence with the car, whereas suburbia everywhere will continue to depend on the car.

\section{Trends in Transport and Communications}

The demand for transport and communications will be determined by the socioeconomic trends outlined. Below, the resulting trends for transport and communications in Europe are discussed.

\subsection{Goods Transport}

The general trend of goods transport in Europe in the past has been growth. Since 1970 goods transport has increased by two thirds. This growth has been unevenly distributed over modes: Traffic on waterways and railways stagnated whereas road goods transport more than doubled.

\section{Inland Waterways}

Sea transport along the coasts and on inland waterways was the dominant mode of goods transport in Europe until two cen- 
turies ago. Today it is only used for bulk goods. Roll-on/roll-off ferries connect the Mediterranean islands, the British isles and Scandinavia with the European continent. The contribution of inland waterway traffic to total goods transport varies between countries depending on their endowment with navigable rivers and canals. In the future the completion of the Rhone-Rhine, Rhine-Main-Danube and Oder-Elbe-Danube canals will improve the market of water transport.

\section{Rail Freight}

Europe has a well developed rail system for goods transport. Without railways the rapid industrialisation of Europe in the 19 th century would not have been possible. Today railway goods transport is losing ground against the truck. On average railways attract less than 20 percent of all goods transport and much less in countries such as Great Britain, Italy and the Netherlands. National railway companies are making great efforts to halt the erosion of their market share by streamlining services, direct over-night freight connections and aggressive freight rates or by promoting various forms of combined road and rail transport such as 'piggyback' trains or 'roadrailer' systems. However, against the unsurpassed speed and flexibility of the truck none of these policies have been really successful.

Without a basic improvement of its competitive situation, railway goods transport is facing further decline. Clientspecific services, further progress in standardisation and containerisation, new freight centres and computerised freight information systems may improve the situation. Many see the introduction of highspeed rail as a possible turning point. The Single European Market will increase average transport distances and reduce custom procedures and thus may offer new opportunities for rail or combined roadrail transport. In particular transit countries like Switzerland and Austria are considering combined transalpine links such as the 'moving motorway' through the Gotthard and Lötschberg base tunnels.

\section{Trucks}

Trucks are at present the dominant mode of goods transport in Europe. In Britain, the homeland of the railway, the truck has replaced goods transport by rail almost altogether. There are several reasons for this. The road network provides accessibility to all corners of the continent. Year by year the road network has been expanded in line with the growing economy, while rail networks in all countries have been constantly reduced. Moreover, with low diesel prices and taxes and roads being financed by the government, truck transport has never covered its true social and environmental costs, in contrast to the railway which has to finance its own infrastructure.

However, the success of the truck is mainly due to its unsurpassed advantage in door-to-door speed, flexibility and reliability. Modern market economies with their multitude of interdependencies and a dispersed settlement structure could not exist without efficient, unbroken, door-todoor transport links. Logistic systems linking supply, production and distribution processes substitute warehousing functions by 'just-in-time' delivery and hence rely on flexible small and mediumsized vehicles.

In the future, all these trends favour the truck. The value of goods transported increases as the standard of living rises and products are becoming more complex. Advances in information processing and telecommunications give rise to new possibilities for complex logistics systems including multimode transport. The logistics revolution within industries is spreading out to inter-industry transport. It has been estimated that goods transport by road will grow by 30 percent due to the Single European Market and the growing internationalisation and deregulation it will bring about. This is likely to present serious congestion problems on motorways, in particular in transit countries as Switzerland and Austria. There will be a relative decline in road infrastructure investments, though peripheral countries will still have a strong interest in new road infrastructure. New roads will face increasing environmentalist opposition.

\section{Air Freight}

Air transport is the fastest, youngest and fastest growing goods transport mode. Air freight will continue its upward trend with the growing internationalisation of the European economies. Deregulation of air transport will lead to greater competition and reduced freight rates. 


\subsection{Passenger Transport}

The last two decades have seen an enormous growth in personal mobility. Since 1970 passenger transport in Europe has almost doubled.

\section{Car}

Today about 80 percent of all passenger- $\mathrm{km}$ in Europe are made by car. This has been accompanied by suburban sprawl around cities, making inhabitants depend on the automobile. The car has become an established and necessary part of life for most families. The success of the car is due to the freedom of movement and almost universal usefulness it offers. It is equally good at short as on long distances, it can be used for carrying people and goods, it requires no mode changes and only minimal planning before starting a journey. Consequently, all forecasts have notoriously underestimated the growth of car ownership and even in the countries with the highest car ownership no saturation is in sight, though the highest growth rates are now in east European countries.

However, in densely populated areas the automobile has already shown its ultimate limits in the form of congestion and unacceptable levels of pollution and noise. In many countries it has become apparent that the solution to urban traffic problems can no longer consist in further expanding the road network but in a synergetic mixture of a variety of policies such as taxation, user charges, traffic restraint, pedestrianisation, and promotion of public transport.

\section{Urban Public Transport}

In many countries it is beginning to be realised that the car and public transport should no longer be seen as competing but as complementary components of urban transport and that therefore part of the costs of public transport should be financed by the general public just as the costs for the road infrastructure.

Electric rail systems have the great advantage of being practically pollution free during operation. However, because of their high costs, commuter rail lines and subways have remained reserved to large cities. For smaller and regional centres, light rail transit (LRT) systems offer affordable solutions with the same service quality as subways. In some countries LRT systems are operated by private companies (e.g. Manchester). Buses serve as feeder to LRT or rail stations, but still are the only mode in small towns and rural areas. The greatest problem for public transport is the provision of adequate service in low-density suburbs or rural areas. In many countries new demand-responsive systems such as dial-a-bus or various forms of paratransit are experimented with.

\section{Long-Distance Rail}

With its dense railway network and generally short distances between its major centres, Europe is ideally suited for rail travel. Eurocity and Intercity trains provide reasonably efficient, comfortable and reliable, though slow, service between the main cities in Europe. For the 1990, a new network of high-speed trains is envisaged, although problems of compatibility between national systems still have to be solved. Figure 3 shows the currently planned highspeed rail network in western Europe:

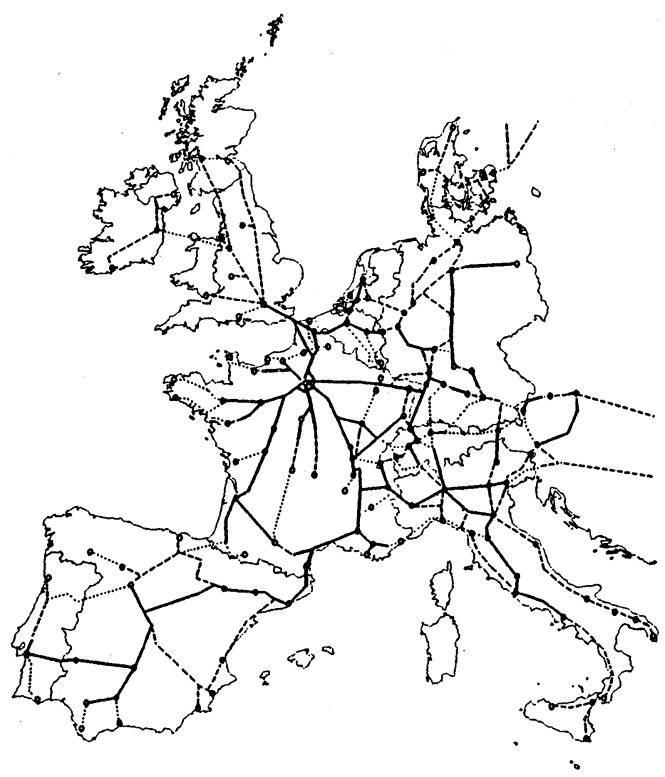

Figure 3. The future high-speed rail network in western Europe.

Trains will run at speeds between 160 and $300 \mathrm{kmh}$, partly on special tracks. Already existing high-speed trains such as the French TGV successfully compete with domestic airlines, so will probably the new German ICE. The German Transrapid, a linear-motor MAGLEV system, still has to find a domestic application. 
The renaissance of the train in longdistance travel will be greatly enhanced by several mega-projects, by which traditional topographical barriers will be removed or substantially reduced: the Channel Tunnel, the two transalpine base tunnels under the St. Gotthard and Lötschberg mountains, and the two bridges across the Danish Storebælt and the Öresund between Denmark and Sweden.

The most spectacular of these is probably the Channel Tunnel. Scheduled to be opened in June of 1993, the 'Chunnel' is likely to change the geography of the continent. Figure 4 shows results of a study about the regional impacts of the Channel Tunnel conducted for the Commission of the European Communities (ACT, IRPUD and ME\&P, 1991). It can be seen that the Tunnel will pull economic activity away from the 'Blue Banana' in westward direction towards the axis London-Paris-Lyon served by the TGV Nord and Sud-Ouest.

Besides investing into faster trains, many national railway companies try to attract more passengers by aggressive marketing, special discounts, service packages custom-tailored to individual groups and new combinations of services such as
'Fly-and-Rail', 'Park-and-Rail', 'Railand-Drive' or car or hotel trains. Another important trend is to develop the railway stations and their environment into major centres of commercial activity, shopping and entertainment.

\section{Air Travel}

During the last decade airline operations in Europe have experienced steady growth rates of five to ten percent per year. Compared to the US and Japan, airline networks and services are still in the beginning of their market penetration and far from saturation.

However, the future development of air travel in Europe will be largely determined by capacity restrictions of airports and air corridors which already today suffer from peak-hour congestion. The pending deregulation of passenger air travel will increase competition between carriers on major routes and lead to the creation of airline-specific hub-and-spoke systems to discourage interlining. Reduced fares and a variety of special discounts will stimulate the demand for air travel at the expense of rail, so will computer reservation systems like Galileo or Amadeus.
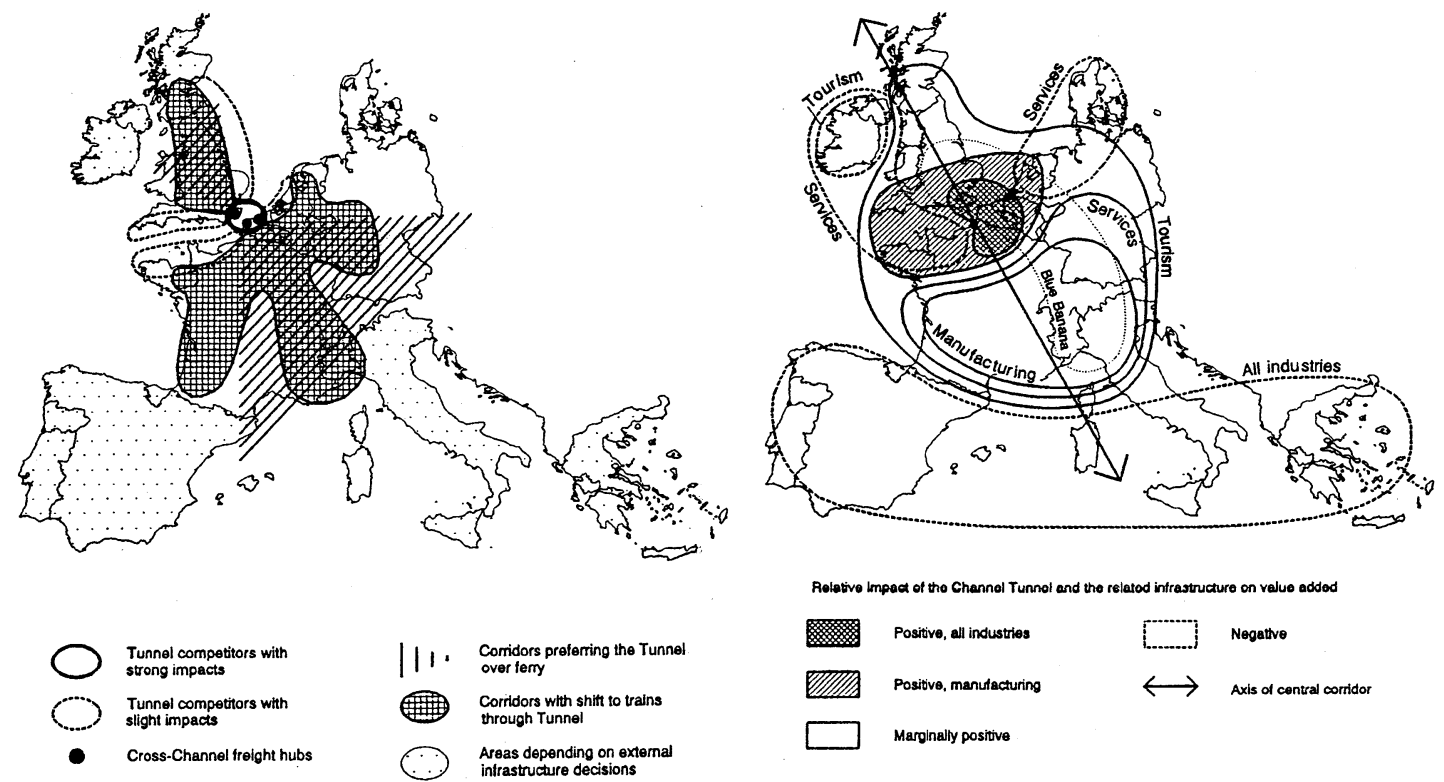

Figure 4. The regional impacts of the Channel Tunnel (ACT, IRPUD and ME\&P, 1991). The Tunnel will attract rail passengers along the future high-speed rail corridors and shift economic activity away from the 'Blue Banana' towards the axis London-Paris-Lyon. 


\subsection{Communications}

There has always been a strong interdependence between telecommunications and economic development. Today telecommunication technologies such as telephone, telefax and computer-to-computer data exchange are indispensable for commercial transactions, industrial logistics and multimodal transport systems.

The growth of the European telecommunications market has been stupendous. The newest and most impressive diffusion phenomenon is the explosive proliferation of facsimile machines. Other new technologies such as packet-switched and value-added networks are spreading steadily, others have experienced uneven acceptance in some countries (e.g. videotext), while others fail to pick up their market as originally expected (e.g. video conferences).

Telecommunication may be a substitute for travel. However, the change from traditional business and working styles has been slower than many observers had anticipated. More fundamental and clearly observable are the impacts of telecommunications on goods transport, where they are at the heart of the logistics revolution.

The newest telecommunications technology in Europe is the Integrated Services Digital Network (ISDN). ISDN will replace various current telecommunications systems by simultaneously transmitting voice, data, text and images. All industrialised European countries are presently developing pilot versions of ISDN using conventional telephone lines working at a speed of $64 \mathrm{~K}$ bits per second (narrowband ISDN), in many countries narrowband ISDN is already available in major cities. Narrowband ISDN is only capable of transmitting voice, data, text and slow-moving monochrome images. In a second phase transmission speeds of multiples of $64 \mathrm{~K}$ bits using fibre optics (broadband ISDN) are planned.

A question still largely unresolved is whether the new telecommunications networks will promote spatial concentration or deconcentration. It seems certain that the more sophisticated systems will be introduced first in regions where demand will make them profitable. This will reinforce the already dominant position of central regions. On the other hand telecommunications will, once widely available, reduce the locational disadvantage of remote regions.
On the intraregional scale, the diffusion of the technology will be faster, so the equalising effect is likely to be dominant. This means that outlying parts of a metropolitan area should become relatively more attractive compared with the core, hence the metropolitan area will decentralise more. However, it is also possible that the need for face-to-face contacts will outweigh this decentralisation tendency in favour of the traditional centre.

\section{Scenarios}

Some of the above trends are powerful processes that cannot easily be changed by human intervention. Others are observable but can potentially be influenced by policy action. Other are very uncertain and cannot easily be predicted.

In such a situation scenario writing is a possible way to reduce uncertainty. Scenarios are descriptions of future developments based on explicit assumptions. As a method for exploring the future, scenarios are superior to more rigorous forecasting methods such as mathematical models if the number of factors to be considered and the degree of uncertainty are high. Scenarios permit the incorporation of qualitative expert judgment, facilitate the process of convergence between different expert views and generate awareness of factors which may have not been identified otherwise.

In the project 'Europe $2020^{\prime}$ conducted by the Network for European Communications and Transport Activities Research (NECTAR) alternative scenarios were developed for the six context fields and three fields of transport and communications presented above (Masser, Svidén and Wegener, 1992). Fore each field three seed scenarios representing different policy directions were developed and assessed by sixty experts form eighteen European countries:

- The Growth Scenario (A). The first scenario shows the most likely development of transport and communications if all policies emphasised economic growth as the primary objective. This would most probably also be a high-tech and marketeconomy scenario, with as little state intervention as possible. This scenario might be associated with the political ideals of many current conservative governments in Europe. 
- The Equity Scenario (B). The second scenario shows the impacts of policies that primarily try to reduce inequalities in society both in terms of social and spatial disparities. Where these policies are in conflict with economic growth, considerations of equal access and equity are given priority. This scenario might be associated with the policy-making of social-democrat governments.

- The Environment Scenario (C). The third scenario emphasises quality of life and environmental aspects. There will be a restrained use of technology and some control of economic activity; in particular where economic activities are in conflict with environmental objectives, a lesser rate of economic growth will be accepted. This scenario might be associated with the views of the Green parties throughout Europe.

The relationship between the three paradigms or political directions can be illustrated by the triangle shown in Figure 5. Each of its corners represents one of the paradigms A, B and C: growth, equity or environment. The present situation is indicated at the centre of the triangle, the triangle area represents the domain of possible changes from the present condition. The line starting from the centre is the trajectory from our present state to the distant future: it may bend in response to technical breakthroughs, new organisational patterns or political decisions.

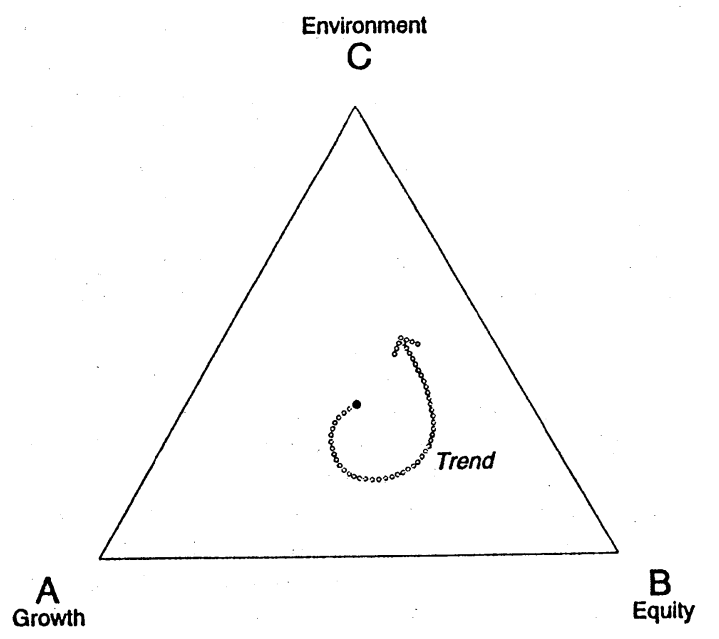

Figure 5. The three paradigms.
A structured questionnaire was used to solicit responses to the seed scenarios and background information provided by the project team.

\section{Which Scenario?}

Growth, equity and environment are three partially conflicting paradigms that will influence the future geography of Europe. Which of them will be the most powerful?

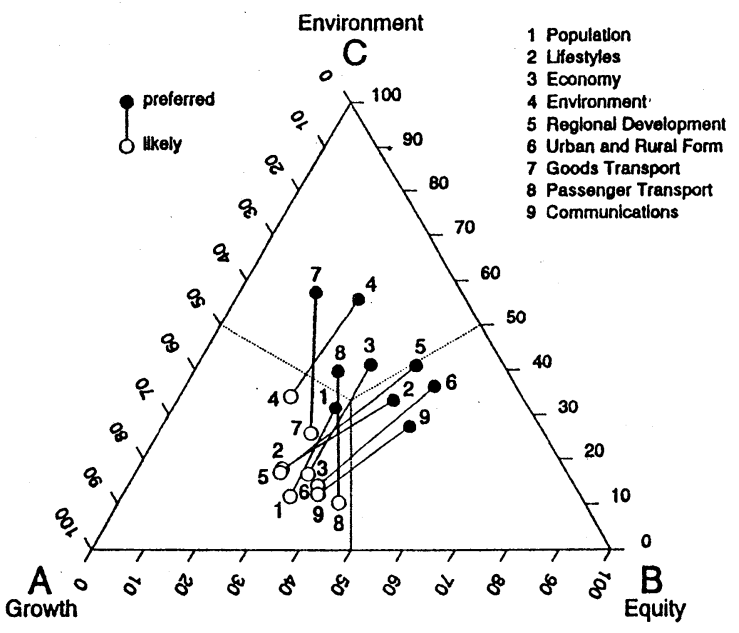

Figure 6. Field scenarios evaluated.

Figure 6 gives the answer. Here the responses are aggregated by the fields discussed above in a triangular coordinate space the corners of which are associated with the three overall goals growth, equity and environment as in Figure 5. Each response, or group of responses, can be located in this coordinate space as a pair of points indicating the 'most 1 ikely' and 'most preferred' scenarios, respectively. The 'most likely' scenario is indicated by a hollow circle and the 'most preferred' scenario by a solid circle. The greater the distance between the two circles, the greater is the dissatisfaction of the respondents with the existing trends.

The result is unequivocal. There is an overwhelming consensus that the growth scenario is by far the most likely and that if present trends continue the market economies of western Europe will continue on their growth path. 
However, there was also disagreement. Is this not a too naive extrapolation of existing trends? The consequences of the unconstrained growth scenario are so negative that it is hard to believe that there would be no action by national and European governments. So a great number of modifications of the growth scenario were suggested, some of which were taken from the other two scenarios. The modifications and suggestions tended to endorse the growth scenario but added some more moderate notes. Nevertheless the outlook remains rather gloomy. If the experts are only partly right, the most likely scenario of transport and communications in Europe is a veritable horror scenario. It presents a continent with an unprecedented level of material wealth and technological perfection yet with unparalleled spatial disparities between its regions and cities, congested roads and a collapsed public transport system, a disappearing countryside and a devastated environment. Are there no alternatives?

The majority of respondents felt that a fundamental change in values and policy making was required. Both the equity paradigm and the environment paradigm found their followers, but clearly the environment paradigm turned out to be the winner. The 'most preferred' scenario hence is a combination of the equity and environment scenarios.

Table 2 shows the essential characteristics of the two scenarios, the 'most likely' and the combined target scenario side by side.

\section{Choices for Europe}

Are there conclusions to be drawn from this analysis that might be useful for decision makers in Europe? The first conclusion is that transport and communications policy cannot be separated from economic, regional, urban and environmental policy. The second is that European policy makers are at a crossroads where two fundamentally opposed directions of political action can be selected. Table 3 confronts these two fundamental options.

The one direction (on the left-hand side of the table) follows the paradigm that because of the global competition with the US and Japan, Europe must do everything possible to modernise its infra- structure and manufacturing equipment and hence promote growth. Underlying this philosophy is that only a growing European economy can pay for the large investments necessary for this global race. However, planning for growth in one of the already richest regions of the world means widening the gap between the industrialised and developing countries with unpredictable consequences for the future. In a competitive economy it also means condoning spatial polarisation, because modernisation is most efficient in the most advanced and most affluent metropolitan regions in the European core. Condoning spatial polarisation, however, means accepting growing disparities between the core regions and the regions at the European periphery, which undoubtedly will benefit from the growth of the centres, but inevitably will grow less than these. Further polarisation also means more agglomeration diseconomies in terms of congestion, land speculation and environmental damage.

The other direction on the right-hand side of Table 3 would be to promote an ecologically sustainable and socially equitable future at the expense of economic growth. This strategy would not only work towards a peaceful solution of the imminent conflict between the developing and the industrialised countries, but also avoid many of the negative aspects of spatial polarisation and environmental degradation inevitably associated with continued economic growth.

For planners and decision makers responsible for transport and communications following the second option would imply:

- In goods transport: to reduce freight transport on roads through fair taxation of trucks taking account of damage of trucks to roads and environmental costs following the 'user-pays' principle, to immediately introduce rigorous environmental standards for trucks and traffic restrictions for trucks in environmentally sensitive areas and congested areas in cities during rush hours or at night in residential districts, to substantially invest in combined road/rail transport facilities and services and to reduce the volume of freight by the relocation of heavy process industries, the regulation of excessive just-in-time logistics schemes and the promotion of regional, short-distance distribution networks. 
Table 2. Summary of likely and preferred scenarios.

\begin{tabular}{lll}
\hline Field & Most likely scenario & Most preferred scenario \\
\hline Population & $\begin{array}{l}\text { Low birth rates, ageing so- } \\
\text { ciety; growth-financed social } \\
\text { security; non-EC foreign } \\
\text { labour without citizenship. }\end{array}$ & $\begin{array}{l}\text { Crisis of social security system } \\
\text { overcome by immigration from de- } \\
\text { veloping countries; government } \\
\text { support of young families. }\end{array}$ \\
\hline Lifestyles & $\begin{array}{l}\text { Singles and 'dinks'model for } \\
\text { lifestyle: efficiency, mobil- } \\
\text { ity, telecommunication, con- } \\
\text { sumption; declassification of } \\
\text { less able. }\end{array}$ & $\begin{array}{l}\text { Change of values: solidarity } \\
\text { instead of competition; renais- } \\
\text { tion in community affairs empha- } \\
\text { sised. }\end{array}$ \\
\hline $\begin{array}{l}\text { Economy } \\
\text { fompire; income disparities } \\
\text { between European core and } \\
\text { periphery and within European } \\
\text { countries. }\end{array}$ & $\begin{array}{l}\text { Europe government promotes sus- } \\
\text { tainable development; taxes on } \\
\text { standards; alternative technol- } \\
\text { ogies }\end{array}$ \\
\hline
\end{tabular}

Environment Serious congestion and transport-generated pollution; massive land consumption for new motorways, high-speed rail lines and airports.

\section{Regional}

Development

Further concentration of economic activities in the European core; agglomeration diseconomies; economic decline in peripheral regions.

Spatial segregation of social groups in cities; suburbanisation of manufacturing; disappearing countryside.

Urban and Rural Form

Dramatic increase in road

Goods Dramatic increase in road

Transport freight transport, toll motorways and bridges; rail freight service disappeared.

Passenger Highly mobile society; domiTransport nance of individual automobility; local public transport declining; competition between car, high-speed rail and air.

$\begin{array}{ll}\text { Communica- } & \text { Massive use of fibre-optics } \\ \text { tions } & \text { and satellite communications; } \\ & \text { 'information society' changes } \\ & \text { lifestyles; dominance of } \\ & \text { large cities reinforced. }\end{array}$

Europe leader in environment-conscious policy making; use of fossil fuels constant; heavy taxes on car ownership and petrol; public transport growing.

Decentralisation programmes and strict land use control in urban areas; incentives for location in peripheral areas; decentralisation of transport infrastructure.

Disincentives for location in large cities; financial aid for small cities; land speculation curbed; car restraint policies.

Restriction and taxation of road freight transport; air freight regulated; promotion of ecological vehicles for distribution.

Car use constrained; renaissance of public transport; clean cars provide harmless mobility for dispersed society.

Use of telecommunications for equalising information in central and peripheral locations; flat telecommunication fares. 
Table 3. Summary of choices for action.

\begin{tabular}{lll}
\hline Field & Growth & Equity/Environment \\
\hline Population & $\begin{array}{l}\text { Permit immigration from non- } \\
\text { EC countries as labour force } \\
\text { without giving them permanent } \\
\text { citizen status. }\end{array}$ & $\begin{array}{l}\text { Embark on zero population-growth } \\
\text { resources; improve support for } \\
\text { families and working parents. }\end{array}$ \\
\hline Lifestyles & $\begin{array}{l}\text { Continue to promote competi- } \\
\text { tion and egoism in education } \\
\text { and economic life. }\end{array}$ & $\begin{array}{l}\text { Support families to reverse } \\
\text { decline in household size; pro- } \\
\text { mote shift in values from indi- } \\
\text { vidual to collective goals. }\end{array}$
\end{tabular}

\begin{tabular}{lll}
\hline Economy & $\begin{array}{l}\text { Continue to serve needs of } \\
\text { transnational companies; con- }\end{array}$ & $\begin{array}{l}\text { Promote small and medium-sized } \\
\text { companies; promote equalisation }\end{array}$ \\
& tinue to deregulation of eco- & of incomes and social security \\
nomy; continue protectionism & within Europe; promote economic \\
against developing countries. & cooperation with Africa.
\end{tabular}

$\begin{array}{lll}\text { Environment } & \text { Continue to settle for lowest } & \text { Plan for sustainable development; } \\ & \text { common denominator for envi- } & \text { adopt environmental standards of } \\ & \text { ronmental standards; continue } & \text { most advanced countries; redirect } \\ \text { to promote high-speed trans- } & \text { transport investments to periph- } \\ \text { port infrastructure. } & \text { eral regions. }\end{array}$

\begin{tabular}{lll}
\hline Regional & Continue to let capital flow & Promote decentralised system of \\
Development & to already prosperous central & regions with autonomy to develop \\
& regions; continue to concen- & their endogenous potential; pro- \\
& trate transport and communi- & mote deconcentration of infra- \\
& cation infrastructure in core & structure. \\
& regions.
\end{tabular}

\begin{tabular}{lll}
\hline $\begin{array}{l}\text { Urban and } \\
\text { Rural Form }\end{array}$ & $\begin{array}{l}\text { Continue to promote winner } \\
\text { cities by concentration of } \\
\text { high-level infrastructure and } \\
\text { not intervening in destruc- } \\
\text { tive competition of cities. }\end{array}$ & $\begin{array}{l}\text { Promote small and peripheral } \\
\text { cities through modern infrastruc- } \\
\text { ture and government agencies; } \\
\text { contain urban sprawl in agglomer- } \\
\text { ations. }\end{array}$ \\
$\begin{array}{l}\text { Goods } \\
\text { Transport }\end{array}$ & $\begin{array}{l}\text { Continue to reward road } \\
\text { freight transport through low } \\
\text { taxation and motorway con- } \\
\text { struction. }\end{array}$ & $\begin{array}{l}\text { Reduce road freight transport by } \\
\text { taxation and regulation; invest } \\
\text { in combined road/rail transport; }\end{array}$ \\
\hline
\end{tabular}

\begin{tabular}{lll}
\hline Passenger & Continue to promote car traf- & Discourage use of cars by taxa- \\
Transport & fic through low taxation, & tion and road pricing; substan- \\
& road construction, dispersed & tially improve the attractiveness \\
& settlements structures and & of public transport; promote re- \\
& neglect of railways. & urbanisation and mixed land use.
\end{tabular}

\begin{tabular}{lll}
\hline Communica- & Continue to promote concen- & Subsidise telecommunications in \\
tions & tration of telecommunications & peripheral regions; introduce \\
& infrastructure in core & flat fare telecommunications \\
& regions. & fares. \\
\hline
\end{tabular}


- In passenger transport: to discourage the use of cars by a differentiated system of taxation, user fees and road pricing taking full account of the environmental and social costs of car driving in general or in particular areas or times of day, while at the same time substantially improving the attractiveness of public transport by new investments, enhanced service and competitive fare structures (acknowledging the fact that public transport is a public good that needs to be subsidised); and to improve the spatial association of residences, work places, shopping areas and public facilities by promoting reurbanisation and mixed land use.

- In communications: to promote telecommunications in peripheral regions by subsidising investments for telecommunications infrastructure and introducing flat fare (not distance-dependent) telecommunication charges - this is the decentralisation option available to dampen the growth of the largest agglomerations by establishing equivalent service, culture and information work opportunities in small cities and peripheral regions.

Unfortunately national governments and the European Commission today predominantly follow the first, the growth option. However, more and more planners and decision makers begin to realise that the rich countries in the world cannot continue to base their culture on the self-propelling dynamics of unconstrained growth. It would be a great challenge for Europe to demonstrate that there is a future that is both equitable and in balance with nature without excessive and destructive material growth.

\section{Acknowledgments}

The author is grateful to the following people for their permission to use material from joint work: Ian Masser and Ove Svidén, co-authors of the forthcoming scenario book (Masser, Svidén and Wegener, 1992), Klaus Kunzmann, co-author of the report on urbanisation in Europe for the European Commission (Kunzmann and Wegener, 1991) and Klaus Spiekermann, Pierre Metge, Sonia Fayman, Ian Williams and Charlene Rohr as project partners in the Channel Tunnel study (ACT, IRPUD and ME\&P, 1991).

\section{References}

ACT, IRPUD, ME\&P (1991): The Impacts of the Channel Tunnel on the Regions in the Community. Report for the Commission of the European Communities. Paris/Dortmund /Cambridge: ACT Consultants, Institute of Spatial Planning, University of Dortmund, Marcial Echenique \& Partners.

Commission of the European Communities (1991): Europe 2000: Outlook for the Development of the Community's Territory a Preliminary Overview. Luxembourg: Office for Official Publications of the EC.

European Round Table of Industrialists (1991) Missing Networks: a European Challenge: Proposals for the Renewal of Europe's Infrastructure. Brussels: European Round Table of Industrialists.

Group Transport 2000 Plus (1990) Transport in a Fast Changing Europe: Vers un Reseau Européen des Systèmes de Transport. Brussels: Group Transport 2000 Plus.

Kunzmann, K.R., Wegener, M. (1991): The Pattern of Urbanisation 1960-1990. Report for the Commission of the European Communities. Dortmund: Institute of Spatial Planning, University of Dortmund,

Masser, I., Svidén, 0., Wegener, M., (1992): The Geography of Europe's Futures. London: Belhaven Press.

Nijkamp, P., Reichman, S., Wegener, M., eds. (1990): Euromobile: Transport and Communications and Mobility in Europe. Aldershot: Avebury.

RECLUS (1989): Les villes 'Européennes'. Rapport pour la DATAR. Paris: La Documentation Française. 